\title{
Physico-Chemical Characterization of Electroplating Industrial Effluents of Chandigarh and Haryana Region
}

\author{
Vikramjit Singh ${ }^{1}$, Chhotu Ram $^{2, *}$ and Ashok Kumar ${ }^{3}$ \\ ${ }^{1}$ Department of Environmental Science and Engineering, Guru Jambeshwar University of Science and Technology, Hisar, India \\ ${ }^{2}$ Department of Civil Engineering, M. M. University, Sadopur, Ambala, India \\ ${ }^{3}$ Corporate Health and Safety Services, New Delhi, India
}

\begin{abstract}
The present study deals with one of India's major concerns is the increasing level of land pollution largely due to the uncontrolled disposal of industrial solid and hazardous waste. The present work carried out on monitoring of various physico-chemical parameters and to evaluate the impact of disposal of electroplating industrial effluent on water quality in Chandigarh and nine districts of Haryana. The various parameters like $\mathrm{pH}$, temperature, Electrical Conductivity (Ec), Total Suspended Solids (TSS), Total Dissolved Solid (TDS), Chemical Oxygen Demand (COD), Biochemical Oxygen Demand (BOD), sulphate, oil and grease, phosphate along with heavy metals viz. chromium, zinc, lead, nickel, cadmium, copper, were tested from effluent treatment plant (ETP) of plating industries. Further, the effects of these constituents on land, groundwater, and surface water bodies were correlated. The results observed from samples indicated that the heavy metal concentrations of chromium from 21.5 to $47 \mathrm{ppm}$, nickel from 72 to 243 ppm, lead from 5.3 to $9.7 \mathrm{ppm}$, zinc from 97 to $731 \mathrm{ppm}$ and copper from 8.4 to $20.7 \mathrm{ppm}$ in effluents in Haryana needs a proper preventive mechanism for sludge treatment, recovery and disposal.
\end{abstract}

Keywords: Contamination; Electroplating effluent; Hazardous waste; Heavy metals

\section{Introduction}

Environmental pollution with metal perhaps begins with the discovery of fire and gradually aggravated to its present alarming level with industrial development and advancement of society. Rapid urbanization and industrialization has led to increased disposal of heavy metals radio nucleotide into the environment [1]. A remarkable increase in use of heavy metals over the past few decades has inevitably redacted in an increased flux of metallic substance concern because of their known accumulation in the food chain and resistance in nature $[2,3]$. Electroplating process involves pretreatment and other preparation, plating, rinsing, passivating and drying. The cleaning and pretreatments stages involve a variety of solvents and surface stripping agents, including caustic soda and a range of strong acids, depending on the metal surface to be plated [4]. In the plating process, the object to be plated is usually used as the cathode in an electrolytic bath [5]. Plating solutions are acid or alkaline and may contain complexing agents such as cyanides. The mixing of cyanide and acidic wastewater can generate lethal hydrogen cyanide gas [6]. Heavy metals such as nickel, copper, zinc chromium, lead, cadmium in wastewater are hazardous to the environment are generated from electroplating industrial effluents, cool burning industries, refining, insecticides, fungicides, iron and steel producing industries $[7,8]$. The solvent and vapors from hot plating bath results in elevated levels of volatile organic compounds (VOC's) and, in some cases, volatile metal compounds, which may contain chromates or metallic ions [9]. Approximately $30 \%$ of the solvent and degreasing chemicals used can be released as VOC's [10,11]. Air emissions may contain toxic organics such as trichloroethylene and trichloroethane. Cleaning or changing of process tanks and treatment of wastewater can generate substantial quantity of wet sludge containing high levels of toxic organics or metals. The limited values given by WHO are as under chromium is $0.1 \mathrm{mg} / \mathrm{L}$, nickel is $0.1 \mathrm{mg} / \mathrm{L}$ and zinc is $5-15 \mathrm{mg} / \mathrm{L}$ in drinking water $[8,12]$. According to IS: 2296-1974 the maximum permissible limit of copper in inland surface water used for public water supply and bathing is $10 \mathrm{mg} / \mathrm{L}$ and according to IS: 33061976 and IS: 7968-1976, tolerance limit of copper for industrial effluent discharge is $3.0 \mathrm{mg} / \mathrm{L}[11,13]$. The electroplating industries are normally focused in this study. The Indian standards for chromium $(0.05 \mathrm{mg} / \mathrm{L})$ and zinc $(5.0 \mathrm{mg} / \mathrm{L})$ in drinking water are Indian standard: 10500-1991 $[2,13,14]$. According to MINAS standards for nickel is $3.0 \mathrm{mg} / \mathrm{L}$, zinc is $5.0 \mathrm{mg} / \mathrm{L}$ and chromium is $0.1 \mathrm{mg} / \mathrm{L}$ in electroplating waste. Various methods employed for removal of heavy metals from effluent such as physicochemical, precipitation of metals as hydroxide, carbonates and sulphides, adsorption on the activated carbon, use of ion exchange resins and membrane separation processes are encountered with certain major disadvantages such as high energy requirements, incomplete metal removal, and generation of a large quantities of toxic waste sludge, which necessitates careful disposal in further steps $[10,11,13]$. Therefore, in present work the effluent samples were collected from effluent treatment plant (ETP) of electroplating industries of Haryana and Chandigarh. Further the characterization of probable parameters including heavy metals investigating and compared with the Indian standard and USEPA standards.

\section{Methodology}

The various effluent parameters from electroplating industries require to be monitored for safe disposal of treated effluent. The effluent samples from outlet of effluent treatment plant (ETP) of electroplating industries were collected and stored at $4{ }^{\circ} \mathrm{C}$ in laboratory. The samples were collected a portion of material small enough in volume to be conveniently transported to a non-reactive bottle for the estimation. This implies, firstly, that the relative portions of the concentrations of all pertinent components must be the same in the sample as in the material being sampled and secondly, that the sample must be handled in such a way that no significant changes in composition occurs before the tests are performed. The various effluent parameters such as $\mathrm{pH}, \mathrm{E}_{\mathrm{c}}$, temperature, total suspended solids (TSS), total dissolved

*Corresponding author: Chhotu Ram, Department of Civil Engineering, M. M. University, Sadopur, Ambala- 234001, India, Tel: +91 8059861043; Fax: + 91- 1752393738; E-mail: chhoturao2007@gmail.com

Received May 25, 2016; Accepted June 06, 2016; Published June 08, 2016

Citation: Singh V, Ram C, Kumar A (2016) Physico-Chemical Characterization of Electroplating Industrial Effluents of Chandigarh and Haryana Region. J Civil Environ Eng 6: 237. doi:10.4172/2165-784X.1000237

Copyright: (c) 2016 Singh V. This is an open-access article distributed under the terms of the Creative Commons Attribution License, which permits unrestricted use, distribution, and reproduction in any medium, provided the original author and source are credited. 
Citation: Singh V, Ram C, Kumar A (2016) Physico-Chemical Characterization of Electroplating Industrial Effluents of Chandigarh and Haryana Region. J Civil Environ Eng 6: 237. doi:10.4172/2165-784X.1000237

Page 2 of 6

solids (TDS), chemical oxygen demand, biochemical oxygen demand, phosphate, sulphate and heavy metals were tested as per the standard method [12]. $\mathrm{pH}$ and $\mathrm{E}_{\mathrm{c}}$ were estimated by the digital $\mathrm{pH}$ meter and electrical conductivity meter. TDS and TSS were measured by the oven method. Phosphate and sulphate were estimated by spectrophotometric method and gravimetric method respectively. Biochemical oxygen demand (BOD) and chemical oxygen demand (COD) of effluent were analyzed by the five day BOD bottle method and titration methods, respectively. The heavy metals analysis such as chromium, zinc, lead, nickel, cadmium, copper, also investigated to evaluate metals concentrations in the effluent and was analyzed using atomic absorption spectrophotometer (AAS). Effluent was characterized using AR grade chemicals as per standard method [12]. Table 1 shows the composition of various tested chemicals from electroplating industry.

\section{Results and Discussion}

This study deals with monitoring of various physico-chemical parameters and to evaluate the effect of the disposal of electroplating industrial effluent on water quality in Haryana and Chandigarh. During sampling 9 districts of Haryana and Union territory (Chandigarh) were chosen because these districts have large number of electroplating industries. Wastewater samples were collected in pre-acid clean plastic containers from the selected locations. Three samples were taken from each location $[15,16]$. Samples were stored with all due precautions in laboratory before estimation. The studied parameters are $\mathrm{pH}$, temperature, $\mathrm{E}_{\mathrm{c}}$, TSS, TDS, COD, BOD, $\mathrm{Cr}, \mathrm{Cu}, \mathrm{Zn}, \mathrm{Ni}, \mathrm{Pb}, \mathrm{Cd}$, oil and grease, sulphate and phosphate. Table 1 represents the composition of electroplating industrial effluents from different locations of Haryana and Chandigarh (Figure 1).

\begin{tabular}{|c|c|c|c|c|c|c|c|c|c|c|}
\hline Parameters & Faridabad & Gurgaon & Yamunanagar & Karnal & Chandigarh & Jagadhri & Panchkula & Panipat & Ambala & Sirsa \\
\hline $\mathrm{pH}$ & 2.2 & 3.2 & 2.8 & 2.5 & 3.8 & 2.9 & 3.2 & 2.8 & 3.2 & 2.6 \\
\hline Temperature & 24 & 26 & 25 & 26 & 24 & 25 & 25 & 26 & 23 & 18 \\
\hline $\mathrm{E}_{\mathrm{c}}$ & 1680 & 1238 & 1254 & 1366 & 1385 & 1250 & 1283 & 1272 & 1315 & 1241 \\
\hline TSS & 675 & 1495 & 1122 & 968 & 1277 & 1440 & 1107 & 1267 & 1011 & 1299 \\
\hline TDS & 360 & 623 & 360 & 344 & 316 & 447 & 452 & 356 & 343 & 392 \\
\hline COD & 473 & 560 & 496 & 520 & 371 & 458 & 561 & 530 & 571 & 506 \\
\hline BOD & 64 & 96 & 90 & 102 & 101 & 100 & 93 & 101 & 97 & 95 \\
\hline Oil \& Grease & 20.1 & 20 & 20.6 & 19.6 & 19.8 & 19.7 & 19.7 & 17.8 & 22.5 & 22.6 \\
\hline Sulphate & 380 & 387 & 347 & 390 & 313 & 286 & 337 & 300 & 248 & 325 \\
\hline Phosphate & 3.5 & 0.6 & 1.1 & 1.5 & 1.2 & 0.78 & 0.77 & 0.8 & 1.18 & 1.1 \\
\hline Chromium & 35 & 34 & 35 & 34.4 & 29 & 27.3 & 47 & 33 & 28 & 21.5 \\
\hline Copper & 16.6 & 8.4 & 13.8 & 20.7 & 18 & 16.2 & 12 & 16.9 & 13 & 11.9 \\
\hline Zinc & 191.6 & 190 & 200 & 158 & 118 & 731 & 331 & 210 & 97 & 160 \\
\hline Nickel & 93.16 & 72 & 90 & 96 & 99 & 215 & 205 & 194 & 243 & 208 \\
\hline Lead & 7.5 & 9.7 & 7.7 & 6.1 & 6.6 & 6.6 & 5.3 & 5.9 & 7.7 & 8.3 \\
\hline Cadmium & 7.4 & 6.4 & 7.8 & 6.7 & 8 & 6.2 & 8.2 & 10.3 & 11.9 & 6.1 \\
\hline
\end{tabular}

Table 1: Characterization of electroplating industry effluents from Chandigarh and Haryana.

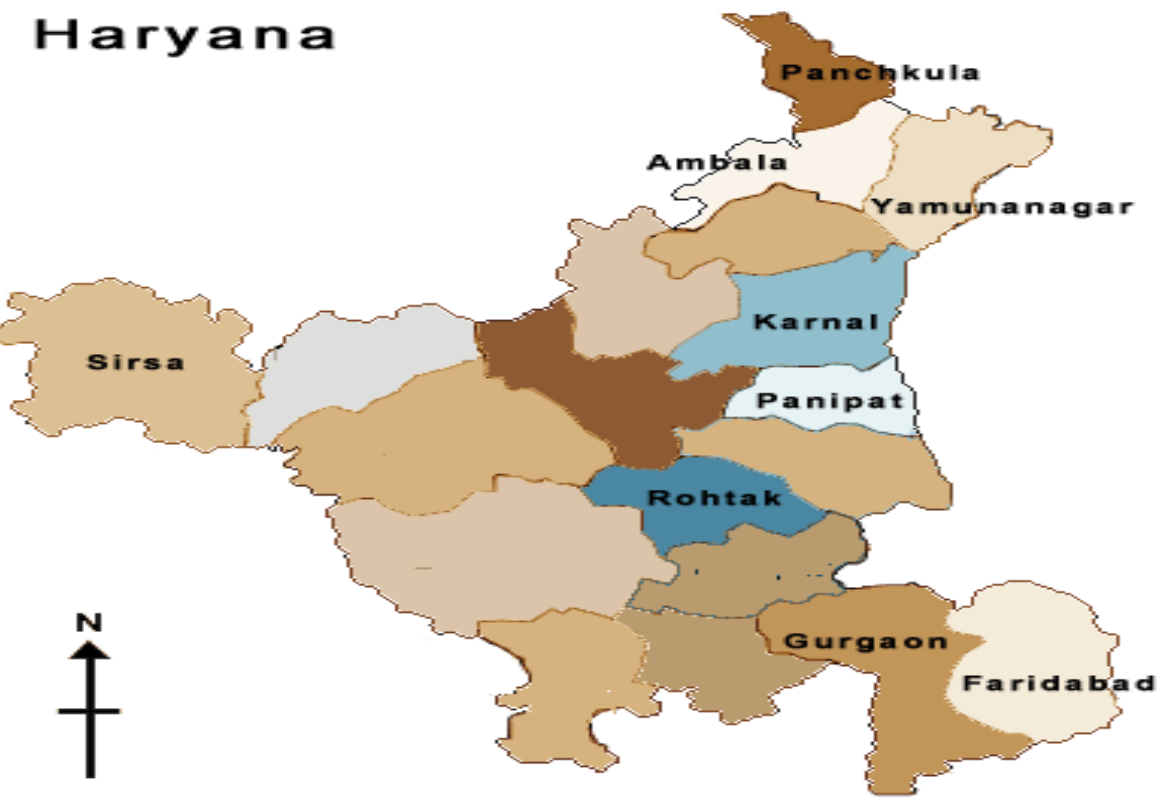

Figure 1: Map shows the various locations of sample taken from different district of Haryana. 


\section{$\mathrm{pH}$, electrical conductivity, total dissolved solids and chemical oxygen demand}

Figure 2 (part A) shows variation in $\mathrm{pH}$ of effluents of all the districts of Haryana varies from 2.2 to 3.8 . The minimum $\mathrm{pH}$ value 2.2 that is of industry situated in district Faridabad shows high acidic condition of wastewater. $\mathrm{pH}$ is a simple parameter, but it is extremely important, as most chemical reactions in aquatic environments are controlled by any change in its value. Aquatic organisms are sensitive towards $\mathrm{pH}$ changes, and biological treatment requires $\mathrm{pH}$ control before treatment. Further, the toxicity of heavy metals is also influenced by change in $\mathrm{pH}$ values [17]. $\mathrm{pH}$ therefore affects the quality of wastewater, and any value higher or lower than 6.5-8.5 limit could be harmful to the environment as per World Health Organization [18].

This is because of using high concentration of acid in the process of cleaning and residual water is drained out. In case of Chandigarh electroplating industry shows $\mathrm{pH} 3.8$ which is also in acidic nature. The permissible limit of $\mathrm{pH}$ of the discharge of electroplating industrial effluent in the range of 7 to 10 . High acidic condition increases the tendency to leach the heavy metal, which are toxic to living being and contaminate the groundwater and soil. The temperature of wastewater varied in the range from $18^{\circ} \mathrm{C}$ to $28^{\circ} \mathrm{C}$. The permissible limits shall not exceed $40^{\circ} \mathrm{C}$ in any sector of stream within 15 meter down streams. It ranges from $18^{\circ} \mathrm{C}$ to $26^{\circ} \mathrm{C}$. Further, electrical conductivity (Figure $2 \mathrm{C}$ ) were examined and samples ranged from $1228 \mathrm{mS}$ to $1680 \mathrm{mS}$ were found. The range of total dissolved solids of effluent sample varies from 343 to $623 \mathrm{mg} / \mathrm{L}$ and shown in Figure 2C. Maximum TDS $950 \mathrm{mg} / \mathrm{L}$ was observed in sample taken from district Gurgaon. The minimum value observed in Ambala and maximum value of TDS observed in Gurgaon and Chandigarh 316. The value of COD varies from 371 to $571 \mathrm{mg} / \mathrm{L}$ and given in Figure 2D and in Chandigarh the concentration is around is $371 \mathrm{mg} / \mathrm{L}$. The minimum value of COD was observed in wastewater of Chandigarh electroplating industries and maximum value observed in Ambala. The prescribed standard of COD is $250 \mathrm{mg} / \mathrm{L}$ in case of industries. The earlier studies also indicated the COD and BOD in metal contaminated industrial effluents [19].

\section{Total suspended solids, biochemical oxygen demand, chromium and phosphate}

Figures 3A-3D represents the variations in the total suspended solid, biochemical oxygen demand, chromium and phosphate. Total suspended solids were represents the variations in the range of entire samples were between 675 to $1495 \mathrm{mg} / \mathrm{L}$. The permissible limits of TSS are $25 \mathrm{mg} / \mathrm{L}$ as per the Indian standards. Minimum value of TSS observed in Faridabad district and maximum value observed in Gurgaon districts Chandigarh ranges at $1277 \mathrm{mg} / \mathrm{L}$. Authors [20,21] investigation on nickel based electroplating industry shows higher amounts of suspended solids. Higher amount of suspended solids may elevate the density and turbidity of water, which in turn may affect the osmoregulation and also interfere with the photosynthesis [20]. Total suspended solids when exceeding the limits are aesthetically unsatisfactory and may cause distress among human beings and livestock [21].

Biochemical oxygen demand is the most widely used parameter of organic pollution applied to both wastewater and surface water is 5 day BOD bottle test. This determination involves the measurement of dissolved oxygen used by microorganism in biochemical oxidation of organic matter for 5 days. The widely recommended limits of BOD are $30 \mathrm{ppm}$. The value of BOD varies from 64 to $102 \mathrm{mg} / \mathrm{L}$. Maximum value of BOD was observed in Karnal is $120 \mathrm{mg} / \mathrm{L}$ and minimum in the
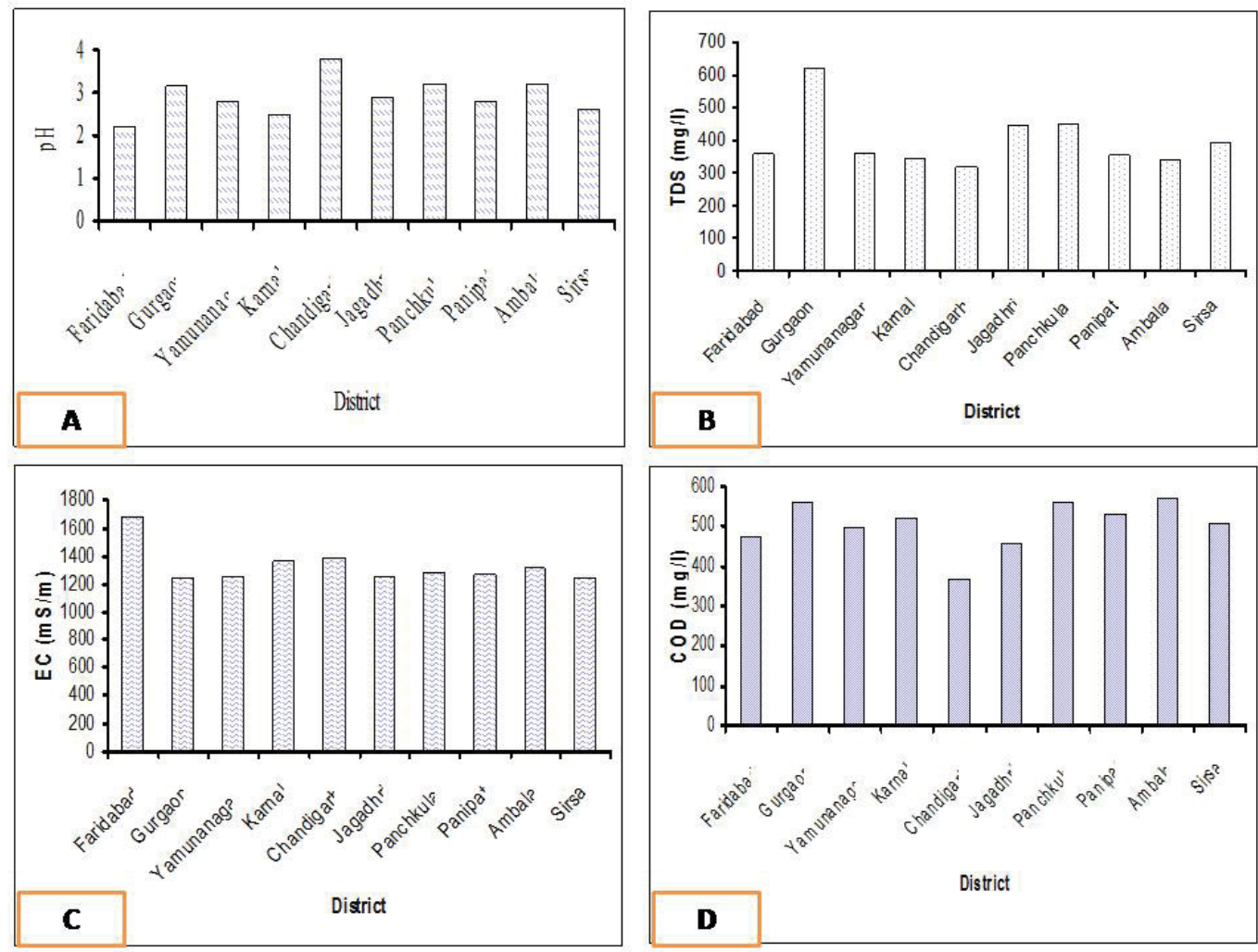

Figure 2: Characterization of electroplating effluents from different district of Haryana and Chandigarh (A). pH (B). TDS (C). $E_{c}(D)$. COD. 

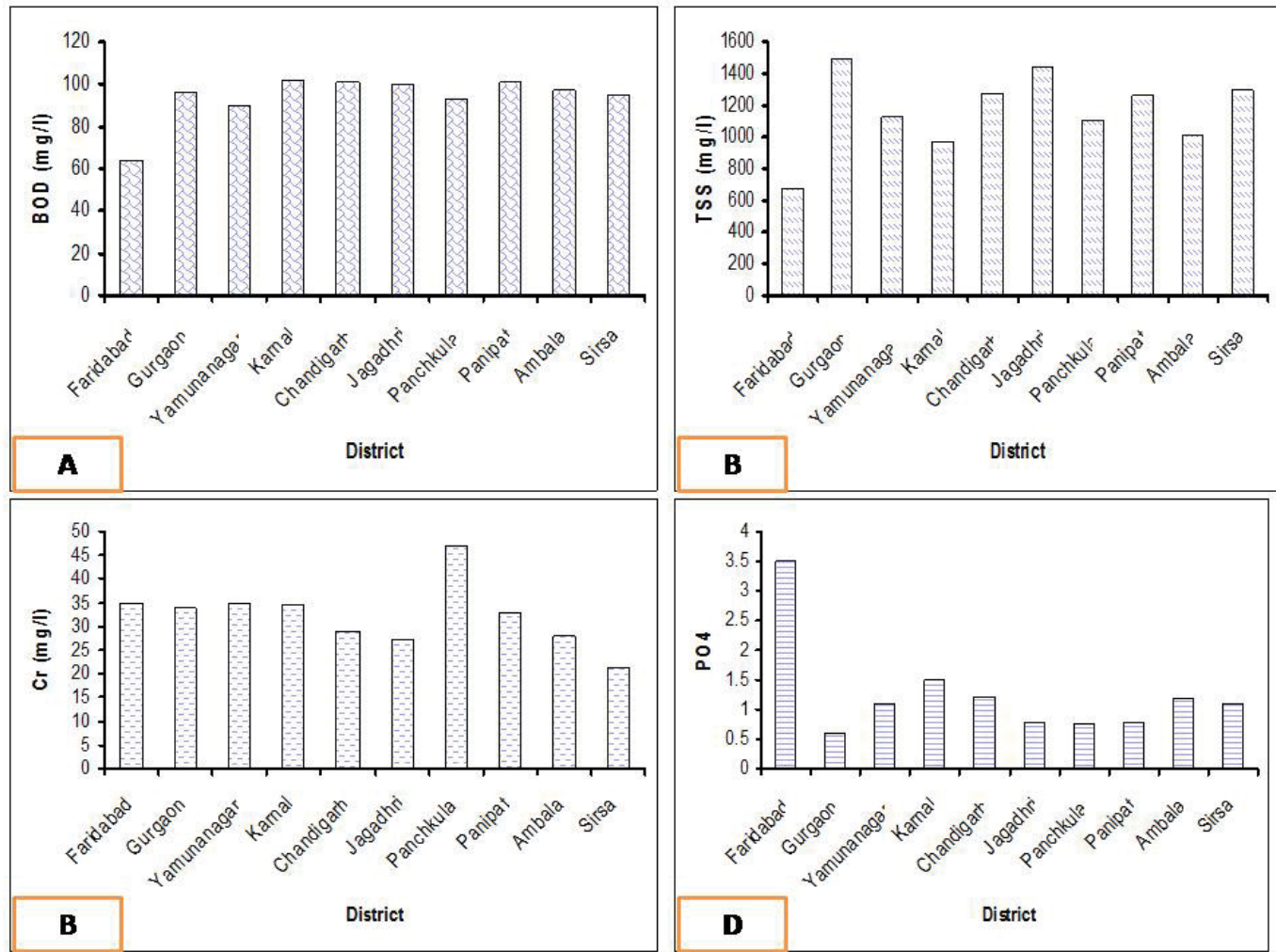

Figure 3: Characterization of electroplating effluents from different district of Haryana and Chandigarh (A). BOD (B). TSS (C). Chromium (D). Phosphate.

district Faridabad. Chromium is present in the effluents primary in the form of its trivalent chromium (III) and hexavalent chromium (VI), plays a vital role in insulin metabolism as the glucose tolerance factor (GTF). Supplementation of chromium (III) has improved the glucose tolerance in diabetes, malnourished children and elder people. The value of chromium varies from 21.5 to $47 \mathrm{mg} / \mathrm{L}$. The Indian standard recommends $0.05 \mathrm{mg} / \mathrm{L}$ of chromium in drinking water. One study reveals that the heavy metals are generated in effluents of tannery industry and their toxic effects are very well established [21]. Further, the phosphate parameters the acceptable limits of phosphate are 5 $\mathrm{mg} / \mathrm{L}$. The range of sample varies from 0.6 to $3.5 \mathrm{mg} / \mathrm{L}$. The maximum concentration of phosphate in Faridabad and minimum in Gurgaon was observed.

\section{Concentration of heavy metals, oil and grease and sulphate}

The heavy metals such as copper, zinc, lead and cadmium were analyzed by the atomic absorption spectrophotometer in collected samples. The concentration of various parameters measured in different industries across Haryana and Chandigarh shown in Figure 4. The range of copper as heavy metal across the Haryana varies from 8.4 to $20.7 \mathrm{mg} / \mathrm{L}$. The maximum value observed in district Karnal whereas and minimum observed in Gurgaon. Chandigarh region electroplating unit has copper value is $18 \mathrm{mg} / \mathrm{L}$.

The maximum value of zinc observed in Jagadhri and minimum in districts of Ambala. The range of zinc varies across the Haryana is 97 to $731 \mathrm{mg} / \mathrm{L}$. The acceptable limit is $5 \mathrm{mg} / \mathrm{L}$. Samples collected from Chandigarh region shows zinc level $118 \mathrm{mg} / \mathrm{L}$. Lead cause serious damage to the nervous system and the brains of unborn children. The range of lead varies from 5.3 to $9.7 \mathrm{mg} / \mathrm{L}$. Maximum concentration of lead in Gurgaon district and minimum concentration of lead in
Panchkula district. Chandigarh unit have observed ranges $6.6 \mathrm{mg} / \mathrm{L}$. The acceptable limit is $0.2 \mathrm{mg} / \mathrm{L}$. Figure 5 shows the variation in cadmium, nickel, oil and grease and sulphate etc. The concentrations of cadmium were observed in the range of 6.1 to $10.3 \mathrm{mg} / \mathrm{L}$. The maximum concentration of cadmium was observed in district Panipat and minimum in Sirsa. The acceptable limit of cadmium is $0.1 \mathrm{mg} / \mathrm{L}$. The heavy metal such as nickel was observed in the range of 68 to 291 $\mathrm{mg} / \mathrm{L}$ in the district of Haryana. Maximum value was observed in district Ambala while minimum in district Gurgaon. The acceptable limit is $2 \mathrm{mg} / \mathrm{L}$. The oil and grease concentration of maximum value of oil and grease observed in Ambala i.e. $26.5 \mathrm{mg} / \mathrm{L}$, and minimum in Chandigarh i.e., $17 \mathrm{mg} / \mathrm{L}$. The acceptable limits of oil and grease are $10 \mathrm{mg} / \mathrm{L}$. The acceptable limit of sulphate is $500 \mathrm{mg} / \mathrm{L}$. The range of sulphate in varies from 24.8 to $390 \mathrm{mg} / \mathrm{L}$ minimum range at Ambala and maximum at Karnal and Chandigarh at $313 \mathrm{mg} / \mathrm{L}$.

\section{Comparison of pollutants with standard}

Table 2 shows the comparison of various contaminants present in the effluent with standards prescribed by the government agency. One can observe that $\mathrm{pH}$, TDS, TSS, oil and grease, COD, BOD and phosphate was found to higher than prescribed standards. However, heavy metals like $\mathrm{Cu}, \mathrm{Cr}, \mathrm{Ni}, \mathrm{Pb}, \mathrm{Zn}$ and $\mathrm{Cd}$ were also present in higher concentration and these metals are very much toxic for our environment. Thus, the electroplating effluents are very much polluting and require proper treatment before disposal into environment. The major objectives of pollutant removal of metals from aqueous solutions are (a) toxicity removal, which entails an environmental aspect and (b) recovery of valuable metals, which involves a technological aspect. Various methods including the conventional ones are available for heavy metal waste management. The commonly used conventional 

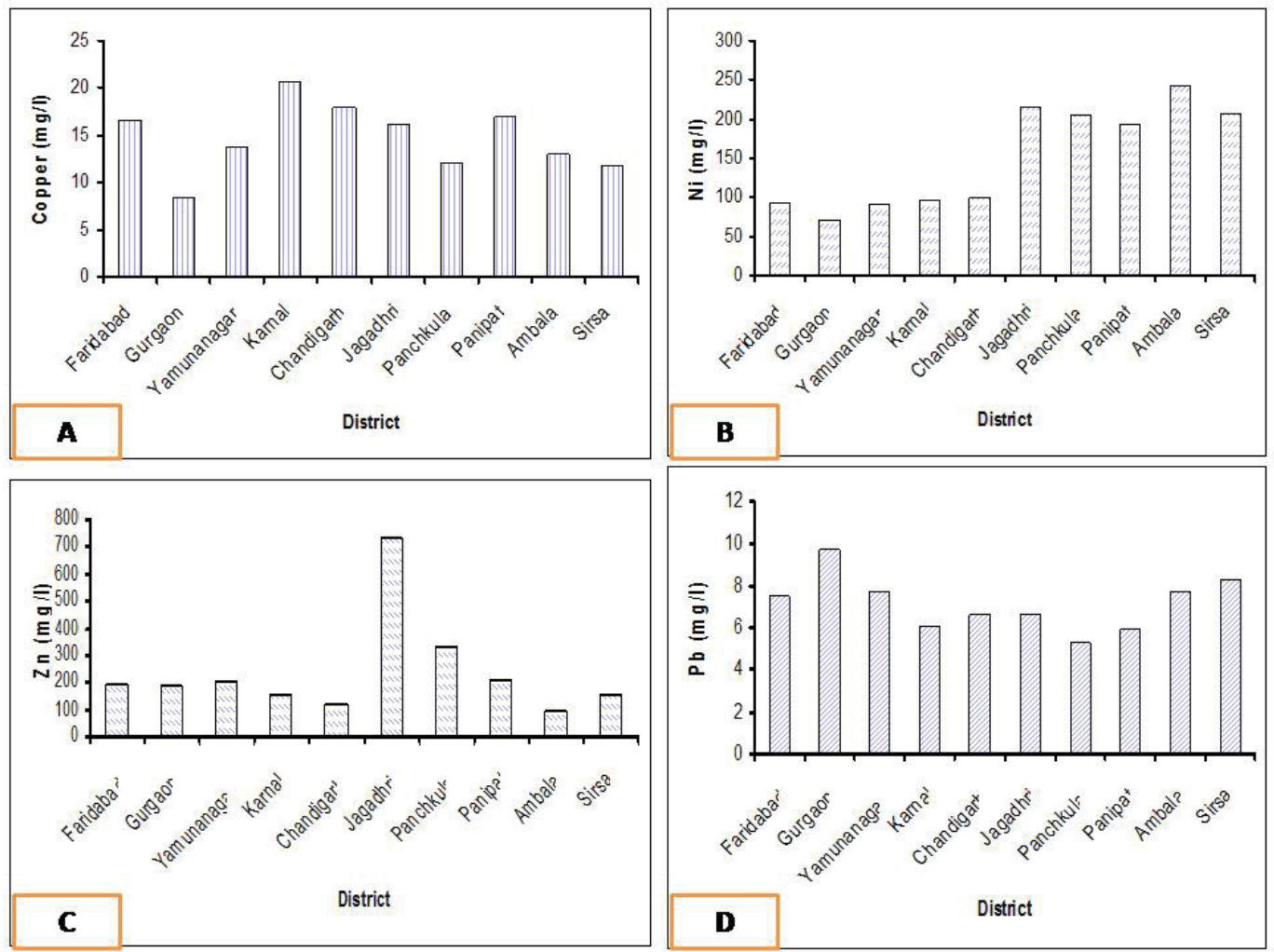

Figure 4: Heavy metals concentration in different parts of Haryana and Chandigarh (A). Copper (B). Nickel (C). Zinc (D). Lead.
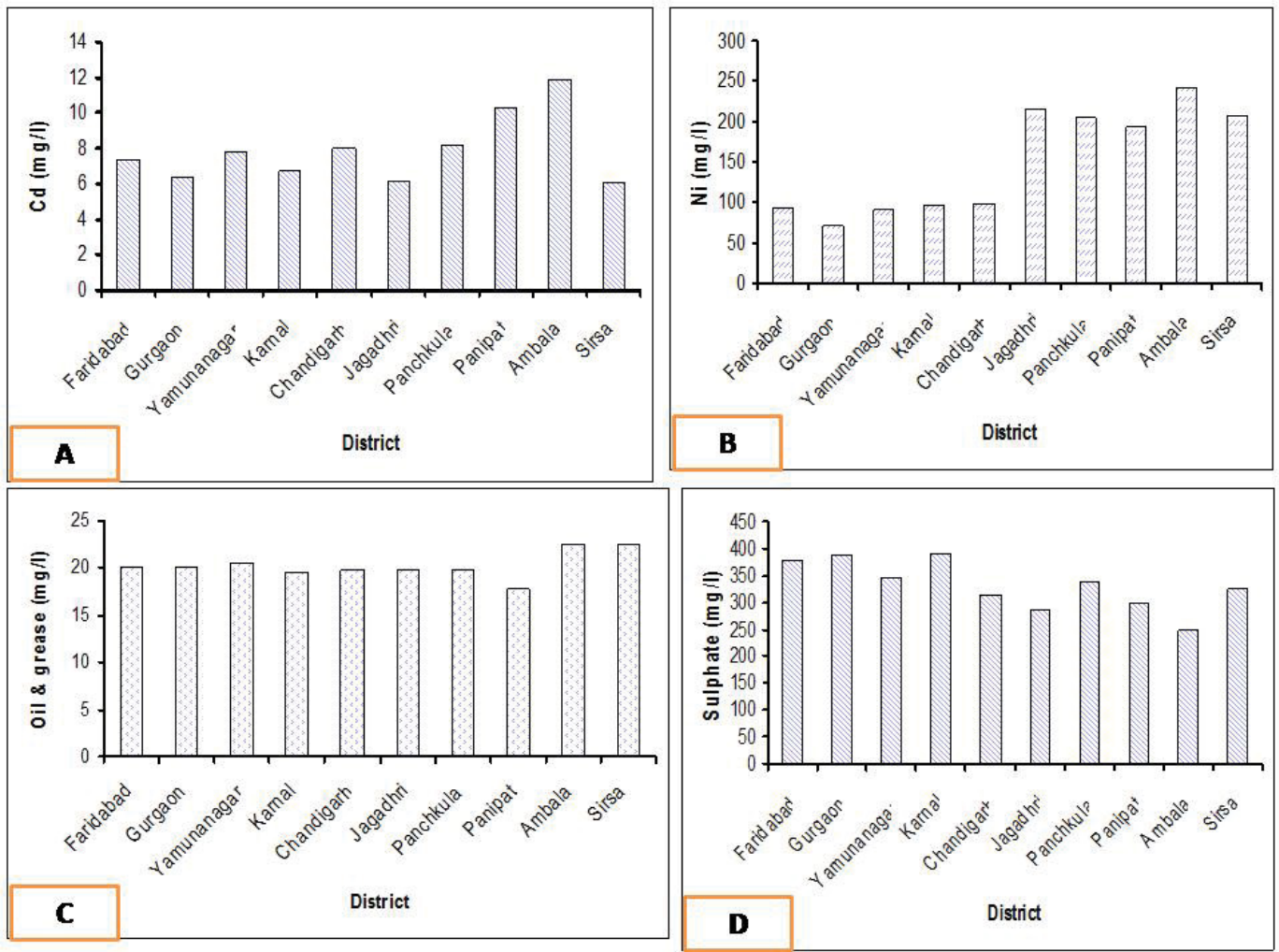

Figure 5: The estimation of various parameters of electroplating effluents from different district of Haryana and Chandigarh (A). Cadmium (B). Nickel (C).Oil and Grease (D). Sulphate. 


\begin{tabular}{|r|c|c|c|}
\hline S. No. & Parameters & Range & Standard \\
\hline 1. & pH & $2.2-3.8$ & $6.5-8.5$ \\
\hline 2. & Temperature & $18-26$ & $<40$ \\
\hline 3. & TSS & $675-1495$ & 20 \\
\hline 4. & TDS & $316-623$ & 500 \\
\hline 5 & COD & $371-571$ & 250 \\
\hline 7. & BOD & $64-102$ & 30 \\
\hline 8. & Oil \& Grease & $17-23$ & 10 \\
\hline 9. & Sulphate & $248-390$ & 500 \\
\hline 10. & Phosphate & $0.6-3.5$ & 5 \\
\hline 11. & Chromium & $21-47$ & 0.05 \\
\hline 12. & Copper & $8-21$ & 0.5 \\
\hline 13. & Zinc & $100-200$ & 5 \\
\hline 14. & Nickel & $72-243$ & 2 \\
\hline 15. & Lead & $10-$ May & 0.2 \\
\hline
\end{tabular}

All values expressed in $\mathrm{mg} / \mathrm{L}$, except $\mathrm{pH}$, temperature $\left({ }^{\circ} \mathrm{C}\right)$

Table 2: Comparison of various pollutants with the standard.

methods include precipitation, ion exchange, adsorption, reverse osmosis, electrodialysis, evaporation, foam floatation, liquid membrane techniques, solvent extraction and crystallization etc. for heavy metal removal. Various techniques used for metal removal recovery are listed. However, the major shortcoming of the conventional treatment includes (a) Low efficiency at low concentration of heavy metals and, (b) Expensive handling and safe disposal of toxic sludge.

\section{Conclusion}

The conditions based on detailed analysis of effluent characteristics from Haryana region and Chandigarh electroplating industries has been studied. The various parameters present in effluents have been correlated with the prescribed standards. It was observed that maximum parameters have been found higher concentrations than the limits prescribed as per government standards. The wastes generated from electroplating industries are identified as hazardous solid and toxic waste. On comparison of heavy metals with standards it was reported that the concentration is very high and is these are very toxic even at low concentration. Since, the leachability of heavy metals such as chromium, nickel, cobalt, iron and copper in effluent also requires proper management including waste minimization, metal recovery, bioremediation using the suitable biosorbants and safe disposal.

Care should be taken for handling such type of effluents in electroplating and metal pickling industries for avoiding contamination of soil and groundwater nearby industry.

\section{Acknowledgment}

The author is highly thankful to Department of Environmental Science and Engineering at Guru Jambeshwar University of Science and Technology, Hisar for help and support.

\section{References}

1. Tamaki S, Frankenberger WT (1992) Environmental biochemistry of arsenic Reviews of Environ Contamination and Toxicol 124: 79-110.

2. Bishnoi NR, Garima (2004) Fungus: An alternative for bioremediation of heavy metal containing wastewater. J Scientific Res 64: 93-100.
3. Delgada A, Anselmo AM, Novais JM (1998) Heavy metal biosorption by dried mycelium of fusarium flocciferum. Wat Environ Res 70: 370-375.

4. Atkinson BW, Bux F, Kasan HC (1998) Consideration for application of biosorption technology to remediate metal- contaminated industrial effluents. Water SA 24: 129-135.

5. Brady D, Stoll A, Ducan JR (1994) Biosorption of heavy metal cation by nonviable yeast biomass. Environ Technol 15: 429-443.

6. Fisher NS (1985) Bioaccumulation of metal by marine pico plankton. Marine Biol 87: 137-142.

7. Jasuja K, Parwana HK, Rao ALJ (1997) Removal of Cr (VI) from aqueous waste using adsorbent from ablesmoschus esculentus (Lady finger plant). In: Indian J Environ 39: 103-108.

8. UNEP (United Nations Environment Programme) (1992) Environmental aspects of the metal finishing industry: A Technical Guide, Paris.

9. Patterson, James W (1985) Industrial wastewater treatment technology. (2ndedn). Boston. Butterworth.

10. Cushnie GC (1985) Electroplating wastewater pollution control technology. Park Ridge, N. J. Noyes Data Corporation (1985).

11. United States Environment Protection Agency, EPA (1980) Proposed guidelines for drinking water quality criteria for the protection of aquatic life and its uses. Federal Register 45: 79-341.

12. Lidsky TI, Schneider, JS (2003) Lead neurotoxicity in children: basic mechanisms and clinical correlates. Brain 38: 259-19.

13. Indian Standards Institution (ISI) (1982) Indian draft standards for drinking water, New Delhi.

14. Panda S (2006) Environmental degradation due to the accumulation of particulates. J of Environ Res Dev 1: 22-25.

15. APHA (1989) Standard methods for the examination of water and wastewater (17thedn) Washington DC

16. Akpomie KG, Dawodu FA (2015) Physico-chemical analysis of automobile effluent before and after treatment with an alkaline-activated montmorillonite. J Taibah University for Sci 9: 465-476.

17. Steenland K, Boffetta $P(2000)$ Lead and cancer in humans: where are we now? Am J Ind Med 38: 259-9.

18. World Health Organization (2003) The World Report: Shaping the future, Geneva.

19. Dwivedi D, Chourey VR (2012) Physico-chemical characterization of water body with special reference to battery, power sources and metal plating effluents. Current World Environ 7: 125-131.

20. Poonkothai M, Vijayavathi BS (2015) Physico-chemical characterisation of nickel electroplating effluent before and after treatment with dead Aspergillus niger. Int Res J Pharma Biosci 2: 01- 13.

21. Shrivastava S, Thakur IS (2003) Biosorption potential of Acinetobacter sp. Strain IST 103 of bacterial consortium for removal of chromium from tannery effluent. J scientific and industrial Res 62: 616-622. 